\title{
Research Article DEVELOPMENT OF LOW COST TIN SOLAR DRYER
}

\author{
KAKADE S.R. ${ }^{1}$, DEVHADE T.P. ${ }^{2}$, PATIL BHAGYASHREE N. ${ }^{3 *}$ AND GUPTA SUCHITA V. ${ }^{4}$ \\ 1,4Department of Farm Structures, College of Agricultural Engineering and Technology, Dr Panjabrao Deshmukh Krishi Vidyapeeth, Akola, Maharashtra 444104, India \\ 2,3Department of Agriculture Process Engineering, College of Agricultural Engineering and Technology, Dr Panjabrao Deshmukh Krishi Vidyapeeth, Akola, 444104, India \\ *Corresponding Author: Email-bhagyashreepatil21@gmail.com
}

Received:December 12, 2017; Revised: December 25, 2017; Accepted: December 26, 2017; Published: January 15, 2018

\begin{abstract}
Solar dryers are specialized devices that control the drying process and protect agricultural produce from damage by insect pests, dust and rain. In comparison to natural sun drying solar dryers generate higher temperatures, lower relative humidity, lower product moisture content and reduced spoilage during the drying process. In order to achieve efficient drying of material with very low cost and less maintenance this study was carried out with an objective to develop solar dryer for domestic use. In this study the performance evaluation of tin dryer was carried out. During the experimental study dryer was made up of tin box, the operational efficiency of dryer was found to be $78.95 \%$ and maximum temperature was found $54^{\circ} \mathrm{C}$ with minimum relative humidity of $18 \%$.
\end{abstract}

Keywords- Solar dryer, Temperature, Relative humidity

Citation: Kakade S.R., et al., (2018) Development of Low Cost Tin Solar Dryer. International Journal of Agriculture Sciences, ISSN: 0975-3710 \& E-ISSN: 0975-9107, Volume 10, Issue 1, pp.-4969-4971. DOl: http://dx.doi.org/10.9735/0975-3710.10.1.4969-4971

Copyright: Copyright@2018 Kakade S.R., et al., This is an open-access article distributed under the terms of the Creative Commons Attribution License, which permits unrestricted use, distribution and reproduction in any medium, provided the original author and source are credited.

Academic Editor / Reviewer: Dr Balaji Murhari Nandede, Kishor Kumar Nag, Manoj Kumar, Thorat Deepak Sabaji, Alok Gora

\section{Introduction}

Drying is a process of removing moisture through simultaneous heat and mass transfer and is a classical method of food preservation that provides longer shelf life, reduced weight and volume. There are three phases in the drying process. The first phase is short and it is the phase during which the drying velocity increases and corresponds to the rise in temperature of the product until it reaches equilibrium. This is the time when the product receives as much heat from the air used to vaporize water. The second phase is the constant drying velocity period. It corresponds to the evaporation of the free water on the surface of the product, which is permanently renewed by the moisture coming from inside of the product. The third phase is the slowing down phase and it corresponds to the evaporation of bound water [1-5].

In industrial drying system the mechanical dryers are very popular but the cost of operation of mechanical dryer is very high which ultimately affects the production cost, therefore the efforts was taken to improve sun drying which leads to solar drying. Studies undertaken so far have clearly indicated that initial cost of solar dryers are high and the life time cost of drying is only a third of dryers based on conventional fuels. So in rural area for drying purpose such dryers are not affordable. to make drying efficient and at low cost we need an dryer of low cost and also low maintenance. Which made us to develop such type of dryer which is used at domestic level [6-10]. That is aim of our project.

The solar dryer is one of the best solutions for drying of fruits and vegetables during energy crises. Due to reduction in moisture content the shelf life of agricultural produce will increased.

Solar dryers are a very useful device for:

- Agricultural crop drying.

- Food processing industries for dehydration of fruits and vegetables.

- Fish and meat drying.

- Dairy industries for production of milk powder.

- Seasoning of wood and timber.
- Textile industries for drying of textile materials, etc.

Thus, the solar dryer is one of the many ways of making use of solar energy efficiently in meeting man's demand for energy and food supply [11-14].

\section{Study Area}

The experimental study was conducted at Department of Agriculture Process Engineering, Dr. Panjabrao Deshmukh Krishi Vidyapeeth, Akola, Maharashtra, India.

\section{Materials and Methods}

\section{A) Material used during experimental process \\ I) Development of dryer from oil tin box}

This work was initiated with the development of tin solar dryer constructed from waste metal oil tin box. Waste oil tin box was purchased from local market cut into desired size and then painted black from outer side. In this dryer three trays were used for drying purpose which made from perforated wire mesh sheet having very small size perforations.

\section{Materials used}

1) Oil tin

An empty oil tin was purchased from local market of size $23 \times 23 \times 33 \mathrm{~cm}$ (lbt). Oil tin was in good condition means no any corrosion and having good structural strength.

\section{2) Acrylic sheet \\ Acrylic is bad conductor of heat so it prevents heat leakage from drying chamber. This sheet was used to construct dryer gate so acrylic sheet of size $23 \times 30 \mathrm{~cm}$. Mainly acrylic was transparent so that it was easy to take reading of temperature by using digital hygrometer inside the dryer by constructing acrylic gate.}




\section{3) Perforated wire mesh sheet}

A perforated wire mesh sheet was used for constructing trays inside the dryer. Three trays were made by perforated wire mesh sheet having size $1 \times 3 \mathrm{ft}$. Openings on the sheet were very small.

\section{4) PVC pipe}

PVC pipe was used for construction of chimney. A PVC pipe of $2.5 \mathrm{~cm}$ diameter and $55 \mathrm{~cm}$ height was used.

\section{5) Black paint}

Black paint was used to paint outer size of dryer to increase absorption efficiency of solar radiation.

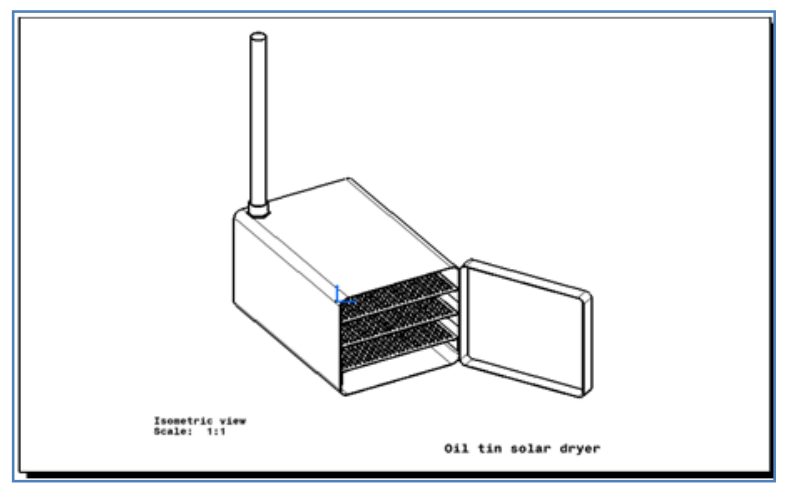

Fig-1 Line diagram Tin box solar dryer

\section{6) Constructional details of tin box solar dryer \\ I) Drying chamber}

Drying chamber of this dryer was simply constructed by oil tin box, it was cut from top side then gate of acrylic was constructed and fitted to drying chamber. In these dryer three trays was constructed so to keep these trays inside the box a metal supports were provided from inner side which was fixed with help of rivets. Construction of this dryer was in horizontal position so dimension of drying chamber was $33 \times 23 \times 23 \mathrm{~cm}(\mathrm{lbt})$. Drying chamber was painted black from outside and handle was fitted at top side.

\section{II) Trays}

Trays were constructed from wire mesh sheet. In this dryer three trays were constructed. Available sheet cut into three parts and metal border was fitted to sheet with help of rivets. Each tray size was $30 \times 22 \mathrm{~cm}$.

\section{III) Chimney}

Air inside drying chamber contains moisture, which have to remove so that there was necessary of air outlet at top surface. So chimney of diameter $2.5 \mathrm{~cm}$ and height $55 \mathrm{~cm}$ was fitted at top surface of dryer.

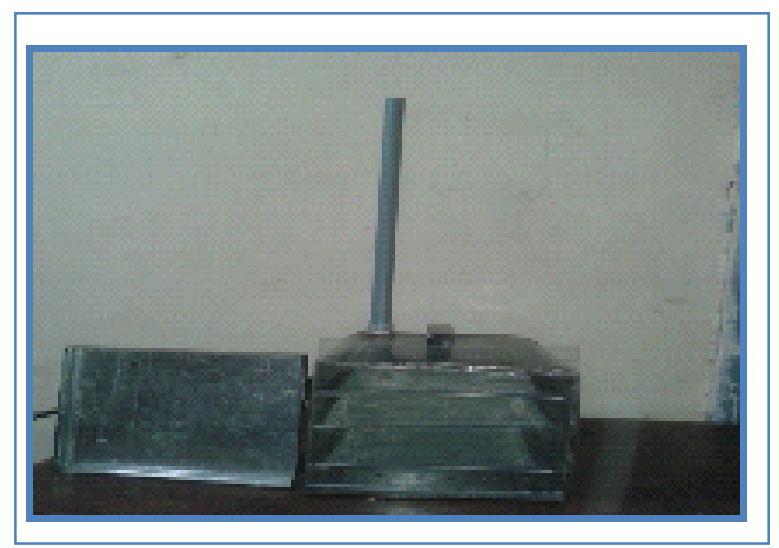

Plate-1 Tin dryer

\section{B) Method followed during experimental work}

A simple box type dryer was developed from waste oil tin box. The curry leaves (drying material) $78.83 \mathrm{~g}$ were uniformly spread in single layer over drying tray having area $0.1818 \mathrm{~m}^{2}$ at the morning $(9.0 \mathrm{~h})$. The temperature and relative humidity in the cabinet was measured at equal intervals of $2 \mathrm{~h}$. After the complete drying process takes moisture loss, drying efficiency and drying rate was determined by using following formula.

Drying Efficiencyn $=\frac{M L \times 100}{M P}$

Drying rate $\frac{d M}{d \theta}=\frac{M L}{t} \times A$

\section{Results and Discussion}

I) Ambient air temperature and relative humidity variation:

At the time of experimental study ambient air temperature and relative humidity was measured by using digital thermometer. The temperature and relative humidity was measure at two hours interval from 9:00 to 17:00 hours. The variation in temperature and relative humidity with respect to time is given in [Table-1] and [Fig-1]. The maximum temperature $\left(348^{\circ} \mathrm{C}\right)$ and minimum relative humidity (41\%) was observed at $13.00 \mathrm{~h}$ (mid of the day). During noon hours gradually decreasing trend in temperature and increasing behaviour in relative humidity was observed.

Table-1 Ambient temperature and Relative humidity with respect to time

\begin{tabular}{|c|c|c|}
\hline Time & Temperature & RH \\
\hline (hrs) & $\left({ }^{\circ} \mathrm{C}\right)$ & $(\%)$ \\
\hline $9: 00$ & 26.3 & 67 \\
\hline $11: 00$ & 32.4 & 50 \\
\hline $13: 00$ & 34.8 & 41 \\
\hline $15: 00$ & 31.5 & 49 \\
\hline $17: 00$ & 32.5 & 49 \\
\hline
\end{tabular}

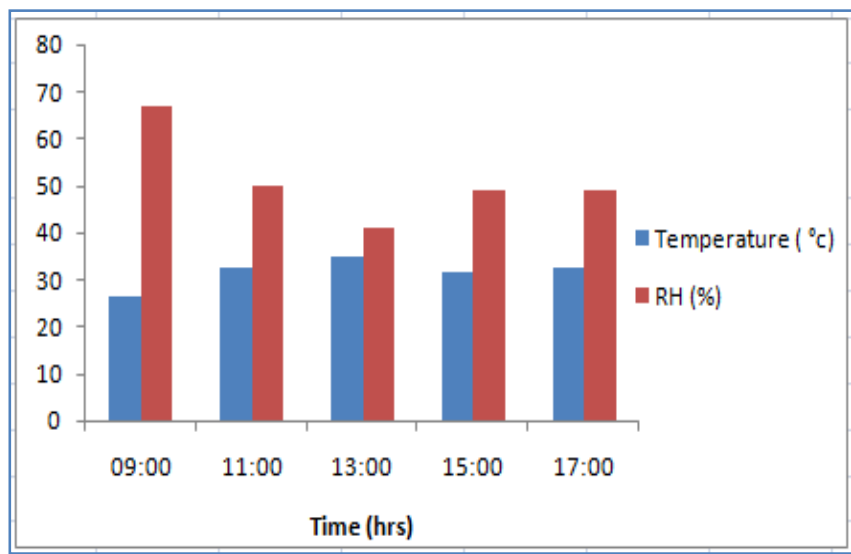

Fig-2 Temperature and Relative humidity with respect to time

II) Air temperature and relative humidity variation inside the tin dryer From [Table-2] it shows that the temperature increases gradually with decreasing relative humidity in the cabinet dryer. This happened due to closed cabinet made by oil tin box. The maximum temperature $54^{\circ} \mathrm{C}$ observed at 15.00 hour and minimum relative humidity was found to be $18 \%$ which was lowest. [Fig-2] shows trend of temperature and relative humidity with respect to time.

Table-2 Temperature and Relative humidity in oil tin dryer w.r.to time

\begin{tabular}{|c|c|c|}
\hline $\begin{array}{c}\text { Time } \\
(\mathbf{h})\end{array}$ & $\begin{array}{c}\text { Temperature } \\
\left({ }^{\circ} \mathrm{c}\right)\end{array}$ & $\begin{array}{c}\text { RH } \\
(\%)\end{array}$ \\
\hline $9: 00$ & 32.0 & 62 \\
\hline $11: 00$ & 44.6 & 29 \\
\hline $13: 00$ & 43.6 & 26 \\
\hline $15: 00$ & 54.0 & 18 \\
\hline $17: 00$ & 44.9 & 28 \\
\hline
\end{tabular}




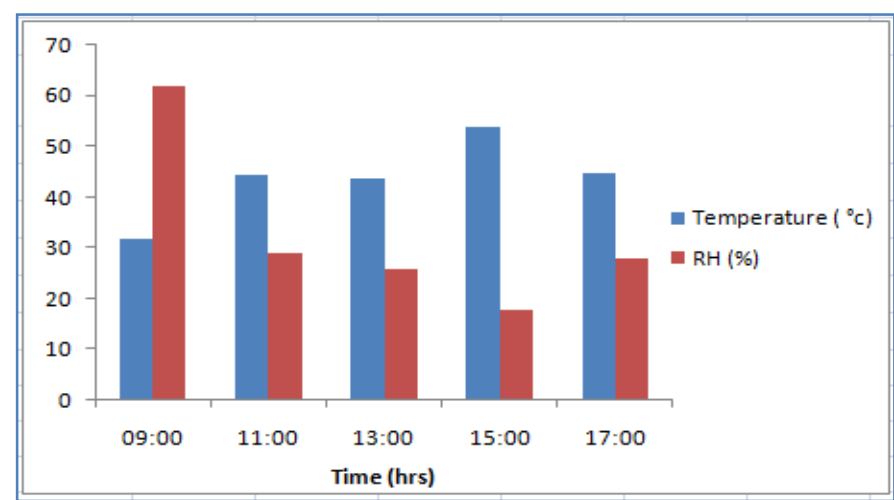

Fig-3 Temperature and Relative humidity in oil tin dryer w.r.to time

\section{Drying Efficiency and Drying Rate}

The dried sample was measured $(40.05 \mathrm{~g})$. The moisture loss was found to be $38.78 \mathrm{~g}$. The dried sample was grind using domestic grinder and the powder was packed in poly bag of 200 gauge. The initial and final moisture content of sample was found to be $62.3 \%$ and $25.82 \%$. The drying efficiency and drying rate of dryer during operation was found to be $78.95 \%$ and $0.027 \mathrm{~kg} / \mathrm{h}-\mathrm{m}^{2}$.

\section{Conclusion}

The ambient temperature and relative humidity was found to be $34.8^{\circ} \mathrm{C}$ and $41 \%$ respectively after $13.00 \mathrm{~h}$ and inside dryer it was found to be $54^{\circ} \mathrm{C}$ and $18 \%$ at $15.00 \mathrm{~h}$, respectively. It was observed that temperature inside the dryer was found maximum as compare to ambient temperature. The drying efficiency and drying rate was found to be $78.95 \%$ and $0.027 \mathrm{~kg} / \mathrm{h}-\mathrm{m}^{2}$.

Application of research: Solar tin dryer is useful for small scale entrepreneurs for drying of fruits and vegetables

\section{Research Category: Agriculture Process Engineering}

\section{Abbreviations: \\ $\%$-Percentage \\ PVC - polyvinyl chloride \\ ${ }^{\circ} \mathrm{C}$ - Degree Celsius}

Acknowledgement I Funding: Author thankful to College of Agricultural Engineering and Technology, Dr Panjabrao Deshmukh Krishi Vidyapeeth, Akola, 444104, Maharashtra, India

\section{*Research Guide or Chairperson of research: Bhagyashree N. Patil}

University: Dr Panjabrao Deshmukh Krishi Vidyapeeth, Akola, 444104, Maharashtra

Research project name or number: Nil

Author Contributions: All author equally contributed

Author statement: All authors read, agree and approved the final manuscript

\section{Conflict of Interest: None declared}

Ethical approval: This article does not contain any studies with human participants or animals performed by any of the authors.

\section{References}

[1] Mirela Militaru, Elena Postelnicu, MihaiChiţoiu and Valentin Vlăduţ (2010) Bulletin UASVM Agriculture, 67(1), 187-193.

[2] Garima Tiwaria, Katiyara V.K., Dwivedia Vivek, Katiyar A. K. and Pandey C. K. (2013) A Comparative study of commonly used Solar Dryers in India, 3(3).

[3] Akachukwu B. Eke and Kayode J. Simonyan (2011) Development and
Evaluation of Small Scale Direct Mode Passive Solar Tomato Dryers,

[4] Medugu D. W. (2010) Archives of Applied Science Research, 2 (1), 336346.

[5] Umogbai V.I and lorter H.A (2013) African Journal of Food Science and Technology, 4(5), 110-115.

[6] Bala B.K., Mondol M.R.A., Biswas B.K., Das., Chaudhary B.L. and Janjai S. (2003) Renewable Energy, 28, 183-190.

[7] Bennamoun Lyes., Belhamri and Azeddine (2003) Journal of Food Engineering, 59, 259-266.

[8] Osman Y. and Can E. (2001) Drying Technology, 19, 583 -597.

[9] Gatea A. A. (2011) African Journal of Agricultural Research, 6(2), 343-351.

[10] Ruslan M.H., Sopian K. and Salleh E. (2013) World Applied Sciences Journal, 22 (3), 424-433

[11] Oguntola J. Alamu, Collins N. Nwaokocha and Olayinka Adunola (2010) Leonardo Journal of Sciences, 71-82.

[12] Yusuf Abdullahi, Musa Momoh and Mahmoud Muhammad Garba (2013) International Journal of Computational Engineering Research, 03.

[13] Jude 0. Ozuomba, Ngozi A. Okonkwo, Bibian C. Uzor and Jude I. (2013) Advances in Applied Science Research, 4(3), 186-194.

[14] Irtwange S. V. and Adebayo S. (2009) Journal of Agricultural Extension and Rural Development, 1(2), 042-049. 